Bibliotech : Jurnal Ilmu Perpustakaan dan Informasi, 3 (2) 2018

\title{
Pengukuran Kemampuan Literasi Digital Orang Tua Menggunakan Instant Digital Competence Assessment (Instant DCA)
}

\author{
Suci Lestari ${ }^{1}$, Indah Kurnianingsih ${ }^{2}$, Wardiyono ${ }^{3}$ \\ ${ }^{1)}$ Pustakawan Al-Azhar \\ ${ }^{2,3)}$ Program Studi Ilmu Perpustakaan Universitas Yarsi \\ *Korespondensi: ${ }^{1)} \frac{\text { scsclestari@gmail.com }}{{ }^{3}{ }^{2}{ }_{\text {wardiyono@yarsi.ac.id }} \underline{\text { indah.kurnianingsih@yarsi.ac.id }}}$
}

\begin{abstract}
ABSTRAK
Pemanfaan internet dalam dunia global terus meningkat. Salah satunya dalam dunia pendidikan keberadaan internet sudah menjadi kebutuhan. Hal ini berpengaruh terhadap peran orang tua dalam proses pendidikan putra-putrinya. Pola komunikasi orang tua terhadap anak memberikan pengaruh terhadap pembentukan sikap dan karakter seorang anak. Orang tua dituntut untuk memiliki kemampuan literasi informasi yang baik di era digital agar mampu menyelaraskan dengan kebutuhan informasi putra-putrinya. Dalam konsep literasi digital seseorang tidak hanya memiliki keterampilan dalam menggunakan berbagai perangkat teknologi informasi dan komunikasi teknologi, tetapi juga untuk proses membaca dan memahami sajian isi dari perangkat teknologi serta proses menciptakan dan menulis menjadi sebuah pengetahuan baru. Penelitian ini bertujuan untuk menganalisis kemampuan lietarsi digital orang tua di SDN 05 Cempaka Putih Jakarta Pusat dalam memanfaatkan sumber-sumber informasi elektronik di internet sebagai sumber belajardengan metode Instant DCA. Metode Penelitian ini menggunakan pendekatan kuantitatif deskriptif . Hasil dari penelitian ini adalah 1) dimensi teknologi; masih ada beberapa responden yang belum memaksimalkan fungsi-fungsi dari perangkat teknologi yang menjadi kebutuhan sehari-harinya, 2) sedangkan dari segi dimensi kognitif; kemampuan responden dalam memanfaatkan internet untuk memudahkan kegiatan sehari-hari sudah cukup baik, 3) dan pada segi dimensi etika; responden telah mampu menjaga hal-hal yang bersifat pribadi di internet dan paham juga akan dampak negatif dari teknologi jika penggunaannya disalahgunakan oleh anak.Besarnya peran orang tua bagi siswa tingkat SD dalam pemanfaatan sumber-sumber informasi elektronik sebagai sumber belajar harus diimbangi dengan kemampuan literasi digital yang baik agar orang tua dapat ikut memberikan kontrol dalam pemanfaatan internet dalam proses pembelajaran.
\end{abstract}

Kata Kunci : Orang Tua, Literasi, Digital,Instant DCA, Sumber Belajar

\section{PENDAHULUAN}

Orang tua memiliki peranan penting dalam proses pendidikan putra-putrinya. Pola komunikasi orang tua terhadap anak memberikan pengaruh terhadap pembentukan sikap dan karakter seorang anak. Dari berbagai hasil penelitan menunjuukkan bahwa orang tua sangat berperan penting dalam tumbuh kembang anak terutama dalam hal pendidikan. Menurut Umar orang tua berperan penting dalam menentukan keberhasilan pendidikan anak-anak mereka. Orang tualah yang paling berperan dalam menentukan prestasi belajar anak (Umar M. , 2015). 
Bibliotech : Jurnal Ilmu Perpustakaan dan Informasi, 3 (2) 2018

Pemanfaan internet dalam dunia global terus meningkat. Saat ini keberadaan internet dalam dunia pendidikan sudah menjadi kebutuhan. Asosiasi Penyelenggara Jaringan Internet Indonesia (APJII) mengungkap bahwa lebih dari setengah penduduk Indonesia kini telah terhubung keinternet. Survei yang dilakukan sepanjang 2016 itu menemukan bahwa 132,7 juta orang Indonesia telah terhubung ke internet. Adapun total penduduk Indonesia sendiri sebanyak 256,2 juta orang. Setelah dikerucutkan kembali berdasarkan data demografi digital di Indonesia, 58,4\% pengguna internet didominasi oleh generasi muda (APJII, 2016).

Perkembangan teknologi informasi yang berkembang pesat menjadi tantangan tersendiri bagi orang tua Agar pemanfaatan internet tidak disalah gunakan, maka orang tua juga harus memberikan perhatian dan bimbingan terhadap anak dalam menggunakan internet yang merupakan bagian dari digital native genarasi yang lahir di era internet. Mayoritas generasi muda saat in hidup di era digital, dimana internet menjadi bagian dari keseharian dalam hidupnya. Hal ini menjadikan generasi muda sangat bergantung pada mesin pencarianseperti google dalam mencari informasi. Oleh sebab itu dibutuhkan pola interaksi orang tua dengan anak dalam menghadapi perkembangan teknologi informasi agar menjadi cara jitu untuk menggunakan internet yang sehat dan aman sebagai media pembelajaran bagi anak. Kondisi ini juga menjadi tantangan baru bagi orang tua untuk memainkan peranan yang lebihpenting dalam mengarahkan putra-putrinya dalam mencari sumber-sumber informasi yang berkualitas dan mendidik mereka untuk mengevaluasi sumber dayaweb.

Berdasarkan latar belakang di atas penelitian ini bertujuan untuk menganalisis pola pemanfaatan sumber-sumber informasi digital oleh orang tua di SDN 05 Cempaka Putih Jakarta Pusat dalam menunjang pembelajaran untuk putra-putrinya ditinjau dari pengukuran instant DCA (Digital Competence Assessment) yang merupakan satu model dan instrumen yang digunakan untuk mengetahui dan mengukur kemampuan literasi digital seseorang. Instant DCA (iDCA) menilai kemampuan literasi digital seseorang dengan membaginya menjadi 3 dimensi yaitu dimensi teknologi, kognitif dan etika. Hasil dari penelitian ini diharapkan dapat menjadi dasar rekomendasi pengembangan materi pemanfaatan internet di kalangan masyarakat khususnya orang tua dalam menunjang proses pembelajaran putraputrinya .

\section{Peran Orang Tua Dalam Pendidikan Anak}

Berbagai penelitian tentang pengaruh keterlibatan orangtua terhadap komitmen belajar siswa telah banyak dilakukan. Beberapa hasil penelitian menunjukkan korelasi positif antara keterlibatan orangtua di sekolah dan komitmen belajar siswa. Penelitian-penelitian tersebut menunjukkan bahwa keterlibatan orangtua di sekolah berpengaruh pada perkembangan 
Bibliotech : Jurnal Ilmu Perpustakaan dan Informasi, 3 (2) 2018

keterampilan regulasi diri anak (Schunk D. P., 2008). Keterlibatan orangtua di sekolah memiliki pengaruh langsung terhadap komitmen siswa di sekolah. Siswa dengan orangtua yang terus memiliki keterkaitan dengan anak dan sekolahnya, terbukti lebih memiliki komitmen tinggi terhadap sekolah dan menunjukkan performansi yang lebih baik (Mo \& Singh, 2008). Pada beberapa penelitian mengenai keterlibatan orangtua di sekolah, telah diidentifikasi berbagai jenis keterlibatan orangtua dalam pendidikan anaknya dan pengaruhnya pada perkembangan anak. Keterlibatan orangtua yang termasuk dalam jenis cognitive - intellectual yang dilakukan melalui pendampingan dalam pengerjaan PR terbukti meningkatkan fungsi psikologis anak yang sebelumnya mempersepsi diri mereka sebagai anak yang kurang kompeten secara akademik .

\section{Literasi Digital}

Martin (2006, p. 155) mengemukakan definisi dari literasi digital sebagai berikut:

"Digital Literacy is the awareness, attitude and ability of individuals to appropriately use digital tools and facilities to identify, access, manage, integrate, evaluate, analyse and synthesize digital resources, construct new knowledge, create media expressions, and communicate with others, in the context of specific life situations, in order to enable constructive social action; and to reflect upon this process."

Pernyataan tersebut menyatakan bahwa literasi digital adalah kesadaran, sikap dan kemampuan individu untuk secara tepat menggunakan alat-alat digital untuk mengidentifikasi, mengakses, mengelola, mengintegrasikan, mengevaluasi, menganalisis dan mensintesis informasi digital,membangun pengetahuan baru, membuat media ekspresi, dan berkomunikasi dengan orang lain,dalam konteks situasi kehidupan tertentu, untuk memungkinkan aksi sosial yang konstruktif; dan untuk menggambarkan proses ini. Hague (2010, p. 2) juga mengemukakan bahwa literasi digital merupakan "the ability to make and share meaning in different modes and formats; to create, collaborate, and communicate effectively and to understand how and when digital technologies can best be used to support these processes.” Berdasarkan pernyataan tersebut, literasi digital berarti kemampuan untuk membuat dan berbagi dalam mode dan bentuk yang berbeda; untuk membuat, berkolaborasi dan berkomunikasi lebih efektif dan untuk memahami bagaimana dan kapan menggunakan teknologi digital yang baik untuk mendukung proses ini.

Definisi lain juga diberikan oleh Sukiman yang merupakan Direktur Pembina Pendidikan Keluarga (2016) bahwa literasi digital mencakup kemampuan dalam penggunaan alat komunikasi untuk mengakses, mengelola, memadukan, menganalisis, dan mengevaluasi informasi yang bermanfaat untuk membangun pengetahuan baru, mencipta, dan mengkomunikasikan dengan orang lain dalam lingkup terbatas maupun masyarakat yang luas. 
Bibliotech : Jurnal Ilmu Perpustakaan dan Informasi, 3 (2) 2018

Berdasarkan beberapa definisi tersebut maka dapat disimpulkan bahwa literasi digital merupakan kemampuan yang dimliki oleh seseorang dalam menggunakan teknologi (termasuk internet), seseorang tersebut mampu mengakses kemudian memahami, mengevaluasi, memanfaatkan dan mengkomunikasikan informasi atau konten yang tercantum dengan benar dan baik.

\section{Instant Digital Competence Assessment (Instant DCA)}

Salah satu model dan intsrumen yang digunakan untuk mengetahui dan mengukur kemampuan literasi digital seseorang adalah Digital Competence Assesment (DCA). The Instant DCA is as a wide-ranged instrument sensitive to various types of knowledge (linguistic and conceptual skills), which can be gauged with a structured test. (Calvani, Antonio et. Al 2008, p. 189). Instant DCA (iDCA) menilai kemampuan literasi digital seseorang dengan membaginya menjadi 3 dimensi yaitu dimensi teknologi, kognitif dan etika (Gambar 1).

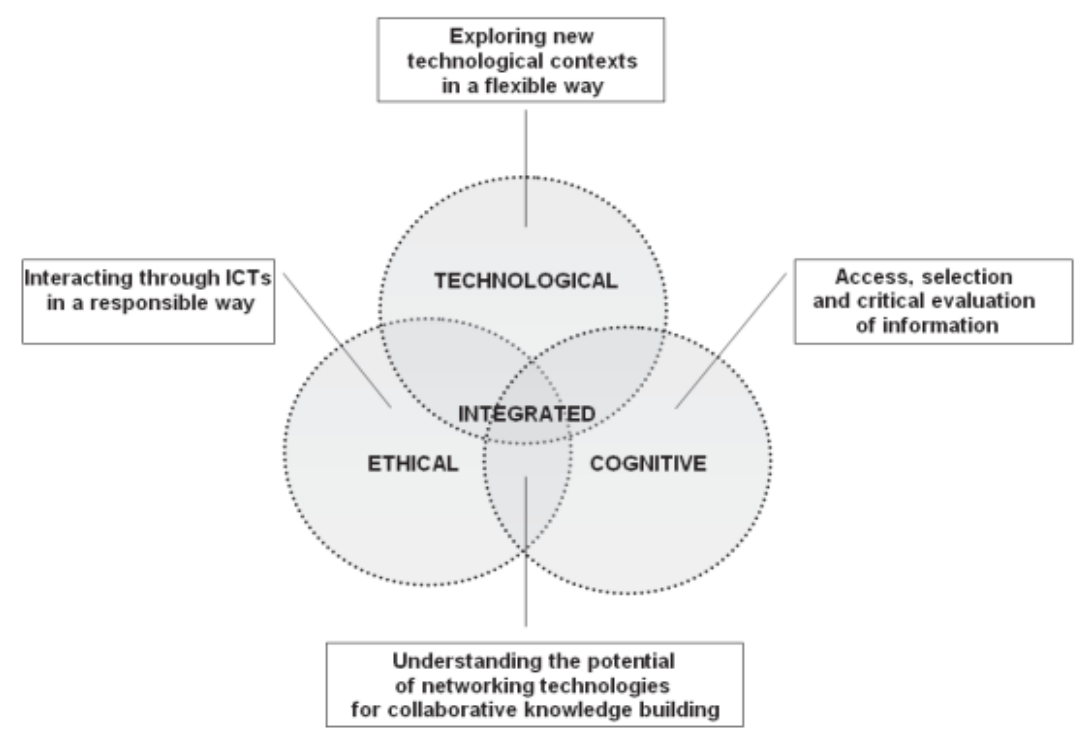

Gambar 1 Instant Digital Competence Assessment (DCA)

Instant DCA dibagi ke dalam sub kategori teknologi, kognitif dan etika. Pada dimensi teknologi terbagi pada beberapa sub yaitu individu mampu mengatasi berbagai kendala seperti permasalahan koneksi dan virus pada perangkat, individu mampu membedakan yang nyata dan virtual. Pada dimensi kognitif memiliki penekana pada kegiatan seperti mampu membuat kesimpulan, membandingkan, menginterpretasikan konten maupun data pada grafik atau pun gambar, mampu memilah informasi yang relevan. Pada dimensi etika terdapat beberapa sub kategori juga seperti individu tidak menyalahgunakan teknologi, menghormati pengguna internet lain dan memahami kensenjangan sosial dan teknologi. 
Bibliotech : Jurnal Ilmu Perpustakaan dan Informasi, 3 (2) 2018

\section{METODE PENELITAN}

Jenis penelitian yang digunakan adalah kuantitatif deskriptif. Penelitian deskriptif merupakan metode penelitian yang berusaha menggambarkan dan menginterpretasikan obyek sesuai dengan apa adanya (Suharsimi, 2002 : 86). Pemilihan metode ini dikarenakan peneliti ingin menggambarkan kemampuan literasi digital orang tua dalam pemanfaatan internet yang sehat dan aman dengan cara menyebarkan kuesioner kepada orang tua di Sekolah Dasar Negeri Cempaka Baru 05 Pagi Jakarta Pusat. Penelitian deskriptif pada umumnya memiliki tujuan utama yaitu menggambarkan secara sistematis fakta dan karakteristik obyek yang diteliti secara tepatdalam pemanfaatan sumber-sumber informasi elektronik di internet oleh orang tua sebagai sumber belajar. Penelitian ini akan mengukur kemampuan literasi digital orang tua yang didasarkan dari teori iDCA yang terbagi menjadi beberapa dimensi yaitu, dimensi teknologi, dimensi kognitif dan dimensi etika

\section{Teknik Pengumpulan Data}

Pengumpulan data pada penelitian ini menggunakan teknik kuesioner. Sugiyono (2014, hlm.192) mengatakan kuesioner merupakan teknik pengumpulan data dimana partisipan/ responden mengisi pertanyaan atau pernyataan kemudian setelah diisi dengan lengkap mengembalikan kepada penulis. Penulis memberikan beberapa pertanyaan dan pernyataan tertulis kepada sampel responden berjumlah 81 orang yang seluruhnya merupakan orang tua SD 05 Cempaka Putih. Pengumpulan data pada penelitian ini menggunakan teknik kuesioner. Penulis menggunakan skala pengukuran Likert pada nomor 16, 17, 18 dan 23. Skala pengukuran ini digunakan untuk mengukur sikap, pendapat dan persepsi seseorang atau sekelompok orang tentang fenomena sosial. Jawaban setiap item instrumen yang menggunakan skala Likert mempunyai gradasi dari sangat positif sampai sangat negatif (Sugiyono 2014, hlm. 136).

Penulis juga menggunakan skala pengukuran Guttman pada nomor 7, 9, 10, 12, 13, 14, $15,19,21,25,26,27,28$ dan 29. Skala pengukuran dengan tipe ini akan didapat jawaban yang tegas yaitu "ya-tidak"; "benar-salah"; "pernah-tidak pernah"; "positif-negatif" dan lainlain (Sugiyono 2014, hlm. 140). Pada jawaban positif atau Ya akan mendapatkan skor 2, sedangkan pada jawaban negatif atau Tidak akan mendapatkan skor 1. Berikut ini merupakan kisi-kisi instrumen untuk mengukur tingkat literasi digital seseorang dengan menggunakan teori iDCA (Instant Digital Competence Assessment). 
Bibliotech : Jurnal Ilmu Perpustakaan dan Informasi, 3 (2) 2018

Tabel 1. Kisi-Kisi Instrumen yang Diperlukan untuk Mengukur Kemampuan Literasi Digital Orang Tua Murid di Sekolah Dasar Negeri Cempaka Baru 05 Pagi Jakarta Pusat.

\begin{tabular}{|l|l|}
\hline \multicolumn{1}{|c|}{ Dimensi } & \multicolumn{1}{c|}{ Sub Dimensi } \\
\hline \multirow{2}{*}{ Dimensi Teknologi } & Recogmizing technological troubles \\
\cline { 2 - 2 } & Identifying interfaces \\
\cline { 2 - 2 } & Selecting the most suitable technological solution \\
\hline \multirow{2}{*}{ Dimensi Kognitif } & Dealing with text (summarizing, representing, analyzing) \\
\cline { 2 - 2 } & Organizing Data \\
\cline { 2 - 2 } & Evaluating relevant information \\
\cline { 2 - 2 } & Evaluating information reliability \\
\hline Dimensi Etika & Safeguarding oneself \\
\cline { 2 - 2 } & Respecting on the net \\
\cline { 2 - 2 } & Understanding social and technological inequality \\
\hline
\end{tabular}

Sumber: Hasil modifikasi dari teori iDCA, Calvani, Antonio et. al (2008 p. 187)

\section{HASIL DAN PEMBAHASAN}

Hasil analisis pembahasan mengacu pada salah satu model dan instrumen yang digunakan untuk mengetahui dan mengukur kemampuan literasi digital seseorang adalah Digital Competence Assesment (DCA). Instant DCA (iDCA) menilai kemampuan literasi digital seseorang dengan membaginya menjadi 3 dimensi yaitu dimensi teknologi, kognitif dan etika. Pada dimensi teknologi terbagi pada beberapa sub yaitu individu mampu mengatasi berbagai kendala seperti permasalahan koneksi dan virus pada perangkat, individu mampu membedakan yang nyata dan virtual. Pada dimensi kognitif memiliki penekanan pada kegiatan seperti mampu membuat kesimpulan, membandingkan, menginterpretasikan konten maupun data pada grafik atau pun gambar, mampu memilah informasi yang relevan. Pada dimensi etika terdapat beberapa sub kategori juga seperti individu tidak menyalahgunakan teknologi, menghormati pengguna internet lain dan memahami kensenjangan sosial dan teknologi.

\subsection{Dimensi Teknologi}

\section{A. Perangkat untuk Mengakses Internet}

Berdasarkan Tabel 2 dapat diketahui bahwa semua responden yang ditemui secara insidentil memiliki smartphone dan 3 responden memiliki lebih dari satu perangkat teknologi. Hal ini dapat dijelaskan bahwa rata-rata smartphone saat ini memiliki fitur-fitur yang mengakomodir berbagai kebutuhan lain selain untuk berkomunikasi yaitu terdapar fitur hiburan berupa musik, kamera, video, permainan dan aplikasi-aplikasi untuk berjejaring sosial sehingga responden dapat memenuhi berbagai kebutuhan (multitasking) dengan hanya menggunakan smartphone karena lebih mudah dan praktis. Berikut ini merupakan data yang didapatkan pada saat penelitian berdasarkan perangkat yang digunakan responden untuk mengakses internet. 
Bibliotech : Jurnal Ilmu Perpustakaan dan Informasi, 3 (2) 2018

Tabel 1 Perangkat untuk Mengakses Internet

\begin{tabular}{|l|c|c|}
\hline Jawaban & Jumlah responden & Persentase \\
\hline Smartphone & 38 & $46,9 \%$ \\
\hline Komputer/PC & 3 & $3,7 \%$ \\
\hline Laptop & 3 & $3,7 \%$ \\
\hline Tablet & 2 & $2,5 \%$ \\
\hline Smartphone dan komputer/PC & 4 & $4,9 \%$ \\
\hline Smartphone dan laptop & 10 & $12,3 \%$ \\
\hline Smartphone dan tablet & 6 & $7,4 \%$ \\
\hline Memakai semuanya kecuali komputer/PC & 6 & $7,4 \%$ \\
\hline Memakai semuanya kecuali tablet & 6 & $7,4 \%$ \\
\hline Memakai semuanya & 3 & $3,7 \%$ \\
\hline Total & 81 & $100 \%$ \\
\hline
\end{tabular}

\section{B. Tindakan Ketika Komputer/PC Atau Laptop Terinfeksi Virus}

Berikut ini merupakan data yang didapatkan pada saat penelitian berdasarkan tindakan responden ketika komputer/PC atau laptop terinfeksi virus.

Tabel 2 Tindakan Ketika Komputer/PC atau Laptop Terinfeksi Virus

\begin{tabular}{|l|c|c|}
\hline Jawaban & $\begin{array}{l}\text { Jumlah } \\
\text { responden }\end{array}$ & Persentase \\
\hline Dibiarkan saja & 10 & $12,3 \%$ \\
\hline Membeli komputer/PC atau laptop baru & 0 & 0 \\
\hline $\begin{array}{l}\text { Pergi ke tempat service komputer/PC atau } \\
\text { laptop }\end{array}$ & 30 & $37 \%$ \\
\hline Mengaktifkan anti virus & 41 & $50,6 \%$ \\
\hline Total & 81 & $100 \%$ \\
\hline
\end{tabular}

Berdasarkan Tabel 3 tersebut dapat diketahui bahwa hanya 41 responden atau 50,6\% mengaktifkan anti virus pada saat komputer/PC atau laptop terkena virus. Dapat diketahui bahwa sebagian responden masih ada yang belum mengetahui tindakan yang tepat saat perangkat terinfeksi virus.

\section{Lokasi Mengakses Internet}

Tabel 4 berikut merupakan data yang didapatkan pada saat penelitian berdasarkan lokasi responden ketika mengakses internet.

Tabel 4 Lokasi Responden Mengakses Internet

\begin{tabular}{|l|c|c|}
\hline Jawaban & Frekuensi & Persentase \\
\hline Tidak tetap/dimana saja & 54 & $50 \%$ \\
\hline Di rumah & 33 & $30 \%$ \\
\hline Fasilitas internet kantor & 10 & $9 \%$ \\
\hline Fasilitas internet tempat hiburan & 4 & $4 \%$ \\
\hline Warnet & 8 & $7 \%$ \\
\hline Lain-lain & 0 & $0 \%$ \\
\hline Total & 109 & $100 \%$ \\
\hline
\end{tabular}


Bibliotech : Jurnal Ilmu Perpustakaan dan Informasi, 3 (2) 2018

Berdasarkan Tabel 4 tersebut dapat disimpulkan bahwa mayoritas responden mengakses internet tidak menetap atau dimana saja. Salah satu kemudahan dalam pencarian informasi menggunakan internet adalah berbagai sumber informasi tersebut dapat diakses kapan saja dan dimana saja selama akses internet tersedia.

\section{Pengetahuan Memblokir Situs Berisi Konten Negatif di Internet}

Berikut ini merupakan data yang didapatkan pada saat penelitian berdasarkan pengetahuan responden mengenai cara memblokir situs yang berisi konten negatif di internet.

Tabel 5 Pengetahuan Responden Untuk Memblokir Situs atau Konten Negatif Di Internet
\begin{tabular}{|l|c|c|}
\hline Jawaban & Jumlah Responden & Persentase \\
\hline Tahu & 0 & 0 \\
\hline Tidak tahu & 81 & $100 \%$ \\
\hline Total & 81 & $100 \%$ \\
\hline
\end{tabular}

Berdasarkan Tabel 5 tersebut dapat diketahui bahwa seluruh responden sama sekali tidak mengetahui bagaimana cara memblokir situs yang berisi konten negatif di internet. Hal tersebut menunjukkan bahwa kurangnya edukasi mengenai pemblokiran situs internet yang berisi konten negatif disekitar responden. Responden atau pengguna perlu diedukasi secara khusus mengenai pemblokiran situs yang berisi konten negatif.

Situs Internetsehat.id memaparkan parental software untuk membantu melindungi keamanan anak di internet dan dipasang di berbgai jenis gadget yang digunakan. Internetsehat.id juga menekankan bahwa parental software hanyalah alat bantu, tidak difungsikan sebagai pengganti peran orang tua. Beberapa aplikasi parental control yang dapat digunakan diantaranya adalah:

1) Qustudio yang dapat diunduh aplikasinya pada situs https://qustudio.com atau melalui playstore untuk Android maupun appstore iOS.

2) K9 WebProtection yang dapat dipasang diberbagai perangkat dan platform (Windows, Apple, Linux, Android, iOS). K9 dapat diunduh secara gratis melalui website http://k9webprotection.com.

3) Kakatu dan layanan DNS Nawala yang merupakan teknologi buatan Indonesia. Kakatu dapat diunduh gratis di http://kakatu.web.id atau melalui playstore Android. Sedangkan untuk menggunakan Nawala, cukup dengan memasukkan nomor DNS pada perangkat laptop atau komputer yang digunakan anak.

\subsection{Dimensi Kognitif}

\section{A. Pemanfaatan Internet dalam Membantu Pekerjaan Rumah Anak}

Peran orang tua dalam proses pembelajaran anak-anaknya sangat dibutuhkan. Berbagai penelitian menunjukkan bahwa pencapaian pelajar meningkat jika orang tua 
Bibliotech : Jurnal Ilmu Perpustakaan dan Informasi, 3 (2) 2018

mengambil peran aktif dalam pendidikan anak-anak mereka. Orang tua harus ikut terlibat dalam pendidikan anak-anak mereka agar prestasi anak dan kedewasaan mentalnya anakanaknya dapat terus berkembang.

Salah satu bentuk keterlibatan orang tua dalam proses pendidikan anak-anaknya adalah membantu anak mengerjakan PR. Pekerjaan rumah adalah tugas yang diberikan oleh guru kepada siswanya untuk dikerjakan di rumah. Ketersediaan informasi elektronik via internet menjadi salah satu cara alternatif yang dapat digunakan oleh orang tua di era digital ini untuk memanfaatkan sumber-sumber informasi elektronik. Berikut ini merupakan data pengalaman responden dalam memanfaatkan internet untuk membantu mengerjakan tugas atau pekerjaan rumah anak.

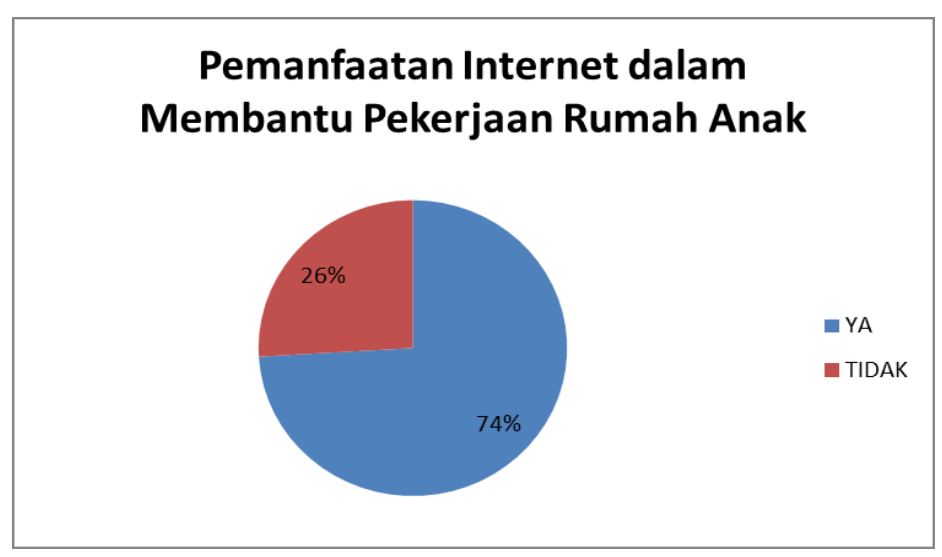

Gambar 2 Pemanfaatan internet sebagai sumber belajar

Sesuai Gambar 2 dapat diketahui bahwa 60 responden atau sekitar 74,1\% telah memanfaatkan internet untuk membantu mengerjakan tugas atau pekerjaan rumah anak. Hal tersebut menunjukkan bahwa mayoritas responden memanfaatkan internet tidak hanya untuk kepentingan hiburan saja melainkan untuk pendidikan anak juga. Salah satu faktor yang mendorong pemanfaatan internet dalam membantu mengerjakan tugas atau pekerjaan rumah adalah factor keterbatan waktu. Bagi beberapa orang tua yang bekerja penuh atau memiliki kesibukan tersendiri, pemanfaatan internet sebagai salah satu sumber bahan ajar merupakan bagian dari solusi untuk mendapatkan informasi yang cepat, efektif, dan efisien. Namun tentunya untuk mendapatkan hasil informasi yang valid para orang tua sebaiknya memiliki bekal keterampilan literasi informasi yang memadai.

\section{B. Pemanfaatan Media YouTube sebagai Sarana Pembelajaran Anak}

Youtube adalah sebuah situs web video sharing (berbagi video) populer dimana para pengguna dapat memuat, menonton, dan berbagi klip video secara gratis. Umumnya videovideo di YouTube adalah klip musik (video klip), film, TV, serta video buatan para 
Bibliotech : Jurnal Ilmu Perpustakaan dan Informasi, 3 (2) 2018

penggunanya sendiri. Namun saat ini Pemanfaatan media Youtube juga digunakan sebagai salah satu sarana sumber belajar.

Salah satu tujuan pemanfaatan youtube sebagai media pembelajaran adalah untuk menciptakan suasana pembelajaran yang interaktif. Bagi orang tua pemanfaatan youtube sebagai media pembelajaran dapat digunakan setiap saat tanpa dibatasi olah ruang dan waktu Berikut ini merupakan data yang didapatkan pada saat penelitian berdasarkan pemanfaatan media YouTube sebagai sarana pembelajaran anak.

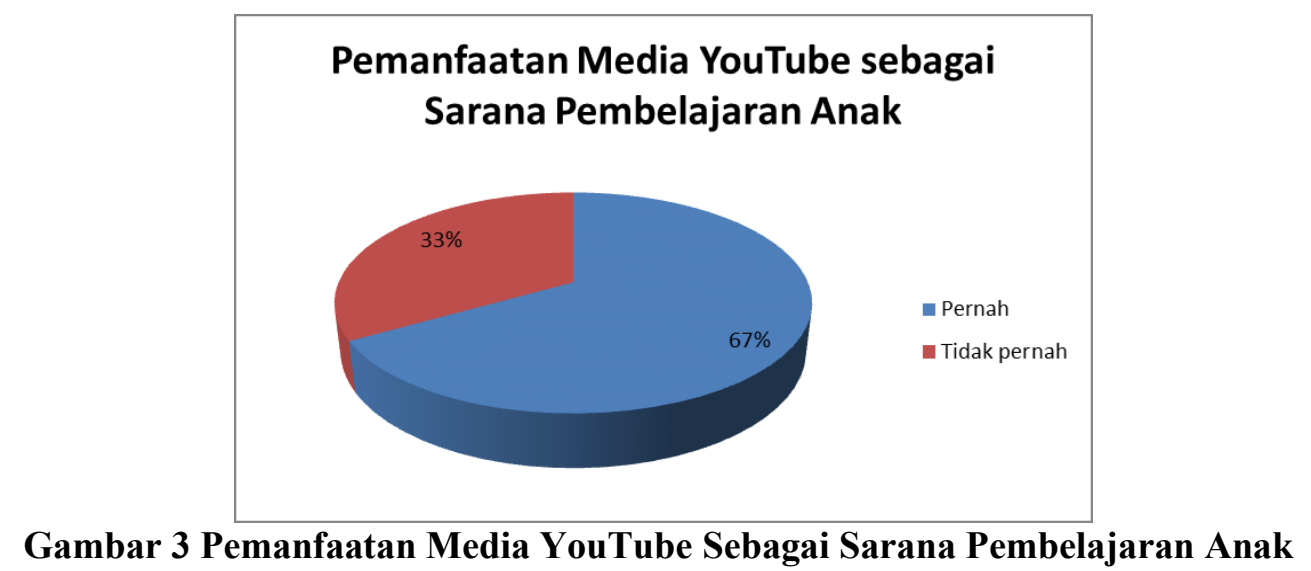

Berdasarkan Gambar 3 tersebut dapat diketahui bahwa 54 responden atau sekitar $66,7 \%$ telah memanfaatkan YouTube sebagai sarana pembelajaran anak. YouTube merupakan sarana pembelajaran yang baik jika dieksplorasi dengan dibimbing dan didampingi orang tua. YouTube meyediakan berbagai video-video baik itu tutorial maupun video berupa film edukasi untuk dijadikan sebagai sarana kegiatan pembelajaran anak serta inovasi YouTube terbaru yaitu terdapat aplikasi YouTube for Kids yang mengkhususkan layanannya pada anakanak dengan menyediakan empat kategori video berupa Shows, Music, Learning dan Explore yang berada dalam lingkup keluarga. Orang tua juga dibantu dengan fitur parent-controller yang merupakan sebuah fitur seperti alarm dimana orang tua bisa mengatur waktu untuk anak-anaknya mengakses YouTube.

\section{Jenis Pemanfaatan Sumber Informasi Elektronik untuk Kegiatan Pembelajaran}

Berikut ini merupakan data yang didapatkan pada saat penelitian berdasarkan kegiatan yang sering dilakukan oleh responden pada saat memanfaatkan sumber-sumber informasi elektronik pada saat membantu kegiatan pembelajaran anak. 
Bibliotech : Jurnal Ilmu Perpustakaan dan Informasi, 3 (2) 2018

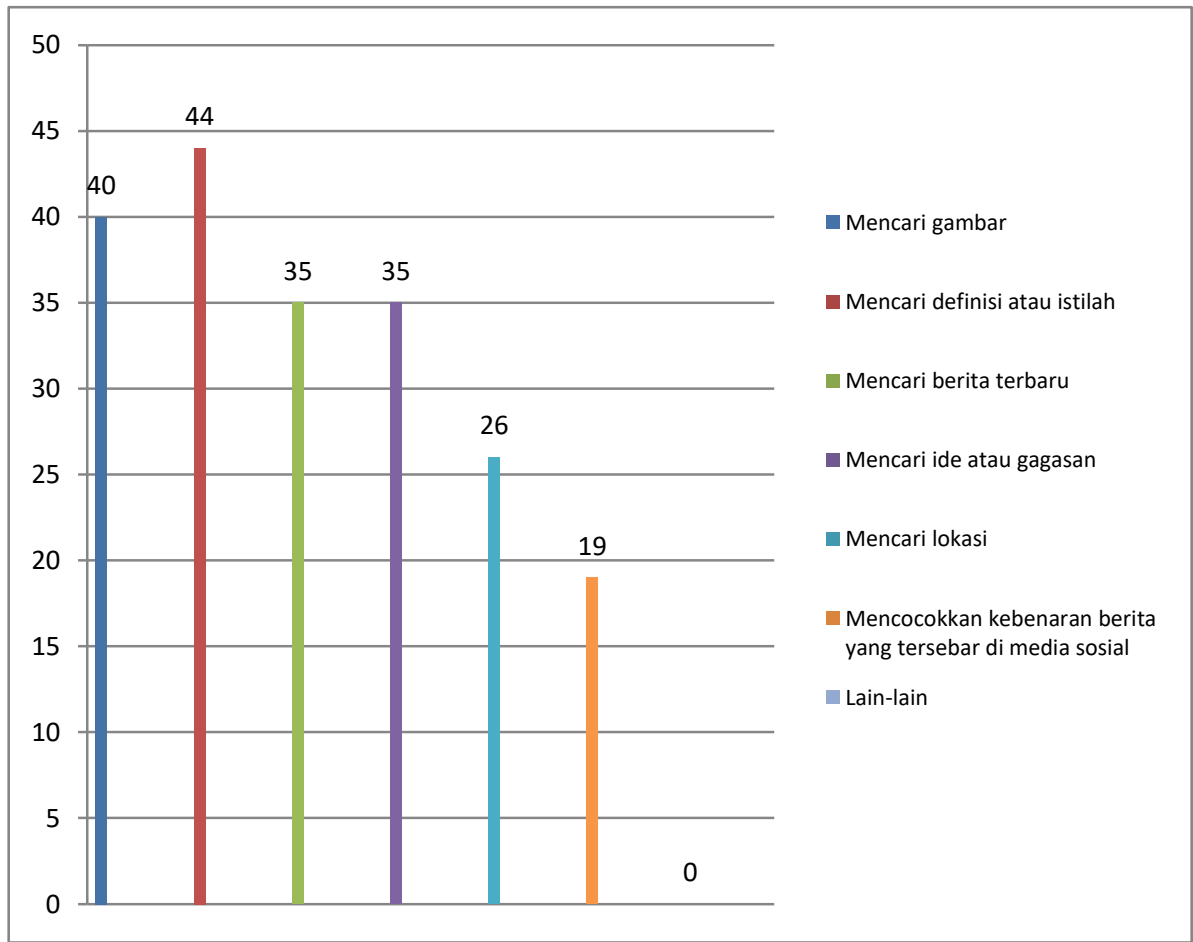

Gambar 4 Pemanfaatan Sumber Informasi Elektronik Untuk Pembelajaran

Berdasarkan data pada Gambar 4 dapat diketahui bahwa kegiatan yang sering dilakukan oleh responden pada saat memanfaatkan sumber-sumber informasi elektronik untuk membantu kegiatan pembelajaran anak yaitu sebanyak 44 responden atau sekitar 22\% memanfaatkan sumber informasi di internet pada saat mencari definisi atau istilah, lalu sebanyak 40 responden atau sekitar 20\% memanfaatkan sumber informasi di internet pada saat mencari gambar, lalu 35 rsponden atau sekitar 18\% memanfaatkan sumber informasi di internet pada saat mencari berita terbaru dan mencari ide atau gagasan, lalu 26 responden laimnya atau sekitar 13\% memanfaatkan pada saat mencari lokasi serta 19 responden sisanya atau sekitar 9\% memanfaatkan sumber informasi di internet pada saat mencocokkan kebenaran berita yang tersebar di media sosial.

Hal ini menunjukkan bahwa pemanfaatan internet sebagai sumber belajar mencakup berbagai bentuk kegiatan. Hal ini sejalan dengan karakteristik dalam literasi digital bahwa keterampilan literasi digital adalah tidak hanya mengacu keterampilan operasi dan menggunakan berbagai perangkat teknologi informasi dan komunikasi teknologi (perangkat keras dan platform perangkat lunak), tetapi juga untuk proses "membaca" dan "memahami" sajian isi dari perangkat teknologi serta proses "menciptakan" dan "menulis" menjadi sebuah pengetahuan baru. 
Bibliotech : Jurnal Ilmu Perpustakaan dan Informasi, 3 (2) 2018

\subsection{Dimensi Etika}

\section{A. Pengetahuan Orang Tua Mengenai Situs/Website yang Valid/Terpercaya}

Ledakan informasi mengharuskan bagi setiap pencari informasi untuk mengevaluasi informasi yang telah didapatkan dari sebuah situs atau web. Beberapa cara mengevaluasi antara lain mengecek otoritas penulis, kemutakhiran, isi informasi serta tampilan web yang disajikan apakah berisi iklan atau kepentingan tertentu.

Berikut ini merupakan data yang didapatkan pada saat penelitian berdasarkan pengetahuan responden mengenai situs/website yang menyediakan sumber informasi yang valid/terpercaya mengenai flu burung (H5N1).

Tabel 6 Pengetahuan Mengenai Situs/Website yang Valid/Terpercaya

\begin{tabular}{|l|c|c|}
\hline \multicolumn{1}{|c|}{ Jawaban } & $\begin{array}{c}\text { Jumlah } \\
\text { Responden }\end{array}$ & Persentase \\
\hline$\underline{\text { https://id.wikipedia.org/wiki/Flu burung }}$ & 33 & $40,7 \%$ \\
\hline$\underline{\text { https://www.deherba.com/apa-sebenarnya-flu-burung-itu.html }}$ & 15 & $18,5 \%$ \\
\hline $\begin{array}{l}\text { http://www.lipi.go.id/berita/opini-:-virus-flu-burung- } \\
\text { berbahaya-bagi-manusia/394 }\end{array}$ & 21 & $25,9 \%$ \\
\hline $\begin{array}{l}\text { www.beritasatu.com/asia/418388-virus-flu-burung-h5n1- } \\
\text { merebak-di-malaysia.html }\end{array}$ & 12 & $14,8 \%$ \\
\hline Total & 81 & $100 \%$ \\
\hline
\end{tabular}

Berdasarkan Tabel 6 tersebut dapat disimpulkan bahwa responden masih belum mengetahui situs yang valid/resmi atau terpercaya dalam mencari suatu informasi. Hal tersebut dapat mengakibatkan responden mendapatkan informasi yang salah sehingga tidak dapat dielakkan bahwa pengguna akan mudah untuk diprovokasi. Wikipedia dominan dipilih oleh responden sebagai situs yang valid/terpercaya untuk mencari persoalan flu burung (H5N1) tersebut. Wikipedia tidak dapat digunakan sebagai rujukan resmi informasi karena siapapun pengguna internet dapat mengubah, menambahkan maupun mengurangi informasi yang tercantum pada Wikipedia.. Jawaban tepat yang seharusnya dipilih responden yaitu http://www.lipi.go.id karena Lembaga Ilmu Pengetahuan Indonesia (LIPI) merupakan lembaga riset negara berkelas dunia dalam penelitian, pengembangan dan pemanfaatan ilmu pengetahuan.

\section{B. Tindakan Responden dalam Penyalahgunaan Internet oleh Anak}

Berikut ini merupakan data yang didapatkan pada saat penelitian berdasarkan tindakan yang dilakukan responden ketika anak kedapatan mengakses konten/isi internet yang tidak sesuai dengan usianya. 
Bibliotech : Jurnal Ilmu Perpustakaan dan Informasi, 3 (2) 2018

Tabel 7 Tindakan Responden dalam Penyalahgunaan Internet oleh Anak

\begin{tabular}{|l|c|c|}
\hline \multicolumn{1}{|c|}{ Jawaban } & $\begin{array}{c}\text { Jumlah } \\
\text { Responden }\end{array}$ & Persentase \\
\hline Biasa saja & 0 & 0 \\
\hline $\begin{array}{l}\text { Melarangnya untuk menggunakan perangkat yang dapat } \\
\text { mengakses ke internet tersebut lagi }\end{array}$ & 25 & $30,9 \%$ \\
\hline $\begin{array}{l}\text { Menasehati dan tetap memberikan perangkat untuk akses } \\
\text { internet kepada anak dengan adanya aturan yang disepakati } \\
\text { oleh Anda dan anak Anda }\end{array}$ & 56 & $69,1 \%$ \\
\hline Total & 81 & $100 \%$ \\
\hline
\end{tabular}

Berdasarkan Tabel 7 tersebut dapat diketahui bahwa 56 responden atau sekitar 69,1\% lebih memilih tindakan untuk menasehati dan tetap memberikan perangkat untuk mengakses internet kepada anak dengan adanya aturan yang telah saling disepakati daripada melarangnya untuk menggunakan perangkat yang dapat mengakses internet ketika anak kedapatan mengakses konten/isi internet yang tidak sesuai dengan usianya. Hal tersebut menunjukkan bahwa responden paham akan pentingnya teknologi pada zaman ini apabila dibentengi dengan memiliki kemampuan pengetahuan dalam memanfaatkan teknologi seperti literasi digital sehingga anaknya tetap diberikan perangkat teknologi walaupun dengan catatan atau kesepakatan yang telah saling disepakati.

\section{Pengetahuan Responden Tentang Etika Menggunggah Kegiatan yang Bersifat Pribadi ke Internet}

Berikut ini merupakan data yang didapatkan pada saat penelitian berdasarkan pengetahuan responden dalam menggunggah kegiatan yang bersifat pribadi ke internet dapat mengancam keselamatan dan keamanan keluarga.

Tabel 8 Pengetahuan Responden Tentang Etika Menggunggah Kegiatan yang Bersifat Pribadi ke Internet

\begin{tabular}{|l|c|c|}
\hline Jawaban & Jumlah Responden & Persentase \\
\hline Tahu & 64 & $79 \%$ \\
\hline Tidak tahu & 17 & $21 \%$ \\
\hline Total & 81 & $100 \%$ \\
\hline
\end{tabular}

Berdasarkan Tabel 8 tersebut dapat diketahui bahwa mayoritas responden sudah tahu akan bahaya mengunggah kegiatan yang bersifat pribadi ke internet dapat mengancam keselamatan dan keamanan keluarga, namun masih ada sekitar 17 responden atau sekitar $21 \%$ tidak tahu akan bahaya mengunggah kegiatan yang bersifat pribadi ke internet dapat mengancam keselamatan dan keamanan keluarga sehingga dapat dilihat pada butir pertanyaan sebelumnya yaitu pada pertanyaan nomor 25, sebanyak 35 responden atau 43,2\% pernah mengunggah foto atau video mengenai kegiatan sehari-hari anak ke internet. 
Bibliotech : Jurnal Ilmu Perpustakaan dan Informasi, 3 (2) 2018

\section{Mengunggah Foto atau Video Pribadi Anak ke Internet}

Berikut ini merupakan data yang didapatkan pada saat penelitian berdasarkan kegiatan menggunggah foto atau video ke internet mengenai kegiatan sehari-hari anak.

Tabel 9 Menggunggah Foto atau Video Pibadi Anak ke Internet

\begin{tabular}{|l|c|c|}
\hline Jawaban & Jumlah Responden & Persentase \\
\hline Pernah & 35 & $43,2 \%$ \\
\hline Tidak pernah & 46 & $56,8 \%$ \\
\hline Total & 81 & $100 \%$ \\
\hline
\end{tabular}

Berdasarkan Tabel 9 tersebut dapat diketahui bahwa sebanyak 46 responden atau sekitar $56,8 \%$ tidak pernah mengunggah foto atau video mengenai kegiatan sehari-hari anak ke internet, namun sebanyak 35 responden atau sekitar 43,2\% responden pernah mengunggah foto atau video kegiatan sehari-hari anak ke internet seperti kegiataan anak saat bermain, belajar, bernyanyi, menari, wisata dan aktivitas sehari-hari lainnya.

\section{E. Tindakan Responden Dalam Mencantumkan Asal Sumber Informasi Sebelum Membagikan Ulang Informasi Tersebut}

Berikut ini merupakan data yang didapatkan pada saat penelitian berdasarkan pengetahuan responden dalam mencantumkan dari mana asal sumber informasi yang didapatkan sebelum mengunggah atau membagikan ulang informasi.

Tabel 10 Tindakan Responden Dalam Mencantumkan Sumber Informasi

\begin{tabular}{|l|c|c|}
\hline Jawaban & Jumlah Responden & Persentase \\
\hline Iya & 37 & $45,7 \%$ \\
\hline Tidak & 44 & $54,3 \%$ \\
\hline Total & $\mathbf{8 1}$ & $\mathbf{1 0 0} \%$ \\
\hline
\end{tabular}

Berdasarkan Tabel 10 tersebut dapat diketahui bahwa sebagian besar responden tidak mencantumkan dari mana asal sumber informasi yang didapatkan sebelum mengunggah atau membagikan ulang informasi tersebut. Kurangnya kesadaran dapat mengakibatkan tindakan penjiplakan dan berita yang dibagikan juga tidak dapat dipertanggungjawabkan kebenarannya.

\section{F. Tanggapan Mengenai Isu SARA Yang Beredar di media sosial}

Berikut ini merupakan data yang didapatkan pada saat penelitian berdasarkan tanggapan responden terhadap isu SARA (Suku, Adat, Ras dan Agama) yang beredar di media sosial. 
Bibliotech : Jurnal Ilmu Perpustakaan dan Informasi, 3 (2) 2018

Tabel 3 Tanggapan Responden mengenai Isu SARA Yang Beredar Di Media Sosial

\begin{tabular}{|l|c|c|}
\hline Jawaban & Jumlah Responden & Persentase \\
\hline Ikut menyebarkan isu tersebut & 0 & 0 \\
\hline Mencari sumber informasi terpercaya & 53 & $65,4 \%$ \\
\hline Tidak peduli & 26 & $32,1 \%$ \\
\hline Marah & 2 & $2,5 \%$ \\
\hline Total & 81 & $100 \%$ \\
\hline
\end{tabular}

Berdasarkan Tabel 11 tersebut dapat diketahui bahwa responden dominan menanggapi isu SARA (Suku, Adat, Ras dan Agama) yang beredar di media sosial secara bijak dengan mencari sumber informasi terpercaya, namun masih ada sekitar 26 responden atau sekitar $32,1 \%$ yang tidak peduli akan hal tersebut. Hal ini menunjukkan bahwa fenomena kehidupan di perkotaan khususnya di Jakarta yang memiliki tingkat individualisme yang tinggi.

\section{Tanggapan Orang Tua Mengenai Pemanfaatan Internet Dalam Proses Belajar Anak}

Perkembangan internet telah memberikan dampak tersendiri di bidang pendidikan. Salah satunya adalah ketersediaan sumber bahan ajar elektrnik yang dapat diakses tanpa dibatasi oleh ruang dan waktu. Berikut ini tanggapan responden orang tua SDN 05 Cempaka Putih Jakarta Pusat terhadap kebermanfatan internet dalam menunjang proses belajar serta pengaruh internet dalam meningkatkan prestasi belajar anak.

Tabel 12 Tanggapan Orang Tua Mengenai Pemanfaatan Internet untuk Menunjang Pembelajaran Anak

\begin{tabular}{|l|c|c|}
\hline Jawaban & Jumlah Responden & Persentase \\
\hline Sangat bermanfaat & 35 & $43,2 \%$ \\
\hline Cukup bermanfaat & 46 & $56,8 \%$ \\
\hline Kurang bermanfaat & 0 & 0 \\
\hline Tidak bermanfaat & 0 & 0 \\
\hline Total & 81 & $100 \%$ \\
\hline
\end{tabular}

Menurut Tabel 12 di atas dapat diketahui hasil mayoritas responden menyatakan sangat setuju $(43,2 \%)$ dan setuju $(56,8 \%)$ hal ini berarti bahwa seluruh responden setuju bahwa internet bermanfaat dalam menunjang pembelajaran anak. Seperti yang kita ketahui, sumber-sumber informasi eletronik di internet terdiri dari beragam jenis yakni visual dan audio visual serta dalam berbagai bentuk dimensi. Sehingga pengguna dapat mengeksplorasi lebih banyak pengetahuan dan informasi tentang suatu topik yang sedang dipelajari.

\section{KESIMPULAN DAN SARAN}

1. Berdasarkan hasil penelitian yang telah diuraikan sebelumnya maka dapat disimpulkan bahwa dari ketiga parameter pengukuran menurut instant Digital competency Asseessment, yakni dimensi teknologi, kognitif dan etika, maka kemampuan literasi digital orang tua siswa Sekolah Dasar Negeri Cempaka Baru 05 Pagi Jakarta Pusat 
Bibliotech : Jurnal Ilmu Perpustakaan dan Informasi, 3 (2) 2018

ditinjau dari aspek teknologi dan kognitif sudah cukup baik. Adapun dari aspek etika, terdapat beberapa kemampuan literasi digital yang perlu ditingkatkan.

2. Kemajuan teknologi informasi berupa internet menimbulkan dampak positif maupun negatif di tengah-tengah bagi masyarakat. Namun tingkat kebermanfaatan dari produk internet ini dikembalikan kepada bagaimana cara pengguna dalam memanfaatakan internet itu sendiri dalam kehidupan sehari-hari. Bagi orang tua yang sudah paham cara menggunakan internet dengan baik serta merasa dimudahkan melalui internet dapat menemukan berbagai sumber informasi dan bahan belajar yang dibutuhkan akan berpendapat bahwa internet telah memberikan pengaruh positif dalam peningkatan prestasi belajar anaknya. Namun sebaliknya, pemanfaatan internet yang tidak sehat dan aman juga dapat memberikan mengaruh negatif terhadap seorang anak. Apalagi jika pemanfaatan internet oleh anak ini tidak diiringi oleh kontrol orang tua maka pemanfaatan internet sangat berpeluang untuk disalahgunakan. Oleh sebab itu di era digital ini orang tua dituntut agar mampu menyelaraskan kemampuan teknologi informasinya dengan perkembangan terkini agar mampu memaksimalkan potensi pemanfaatan internet untuk hal-hal yang mendukung proses belajar putra-putrinya.

\section{DAFTAR PUSTAKA}

APJII. (2018). Penetrasi \& Perilaku Pengguna Internet Indonesia Survey. Jakarta: APJII. https://apjii.or.id/downfile/file/BULETINAPJIIEDISI23April2018.pdf

Arikunto, S. (2006). Prosedur Penelitian: Suatu Pendekatan Praktek. PT Rineka Cipta: Jakarta

Calvani, A. et all. (2008) Models and Instruments for Assessing Digital Competence at School, Journal of e-Learning and Knowledge Society, vol.4, no. 3, hlm. 183-193, (online ResearchGate)

Hague, C., \& Payton, S. (2010). Digital Literacy Across the Curriculum: a Futurelab Handbook. United Kingdom. https://www.nfer.ac.uk/publications/FUTL06/FUTL06.pdf

Martin, A. (2006). 'A European Framework for Digital Literacy', Nordic Journal of Digital Literacy, vol.1, no.2, p.151-161. Diakses 27 Januari 2017, https://www.idunn.no/file/pdf/33191479/a_european_framework_for_digital_literacy.p df

Mo, Y., \& Singh, K. (2008). Parents' relationships and involvement: Effects on students' school engagement and performance. RMLE Online, 31(10). 
Bibliotech : Jurnal Ilmu Perpustakaan dan Informasi, 3 (2) 2018

Schunk, D. P. (2008). Motivation in Education: Theory, Research, and Applications. Upper Saddle River: Pearson Education .

Sukiman. (2016). Literasi Digital Keluarga untuk Perlindungan Anak.

http://www.slideshare.net/idigf/id-igf-2016-sosbud3-literasi-digital-untuk-keluarga

Umar, M. (2015). Peranan Orang Tua Dalam Peningkatan Prestasi Belajar Anak. Jurnal

Edukasi, 1. http://dx.doi.org/10.22373/je.v1i1.315 
Bibliotech : Jurnal Ilmu Perpustakaan dan Informasi, 3 (2) 2018 